\title{
FORMATION OF STUDENTS' TOLERANT ATTITUDE TO PEOPLE WITH SPECIAL NEEDS
}

\author{
NATALIIA MATVEIEVA
}

\begin{abstract}
The article substantiates the relevance of the problem of raising tolerance of younger schoolchildren to people with special educational needs. The analysis of the level of readiness of all members of the educational process for communication, co-stay, education with students with violations in development; specifics of educational influence on younger students on the formation of stable moral beliefs, cultivation of moral features and qualities, development of spirituality, appropriation of values which are essential and necessary in the context of the arrangement of the inclusive, and educational environment of the New Ukrainian School. The emphasis is placed on the need to include students without exception in various activities, organizing and conducting joint creative work, educational events and games for the purpose of disclosing the inner world of children, studying their peculiarities, and strengthening the children's friendship. It is emphasized that observance of a number of requirements can increase the efficiency of the process of raising tolerance towards children with special needs.

Keywords: children with special educational needs, inclusive education, individual approach, adaptation, modification, equality, upbringing, tolerance.
\end{abstract}

\section{INTRODUCTION}

The present time confirms that in the field of Ukraine's education there is a revision of approaches to determining the priority directions of the development of modern educational institutions, reorganization of traditional forms and methods of teaching and upbringing of the younger generation, and identification of the most effective ways of providing high-quality educational services. Not only temporal changes, community demands to the level of education and the quality of the acquired knowledge serve this purpose, but also the social aspect of the problem of preparing the future generation for further life. Thus, the characteristic features of changes and transformations in the educational sphere today are the review of the attitude towards the personality, its possibilities; approaches, forms and methods for its comprehensive development; making adjustments to the content and organization of the educational process. In connection with the reform of education in Ukraine on the model of developed European states, guided by world-known normative documents, which are based on equality, democracy, humanism in relation to men and their rights [8], the tasks faced by the modern school are tightly associated, in the first place, with its normative and legal provision. 
According to the Concept of the New Ukrainian School, the goal of every educational institution today is to create comfortable conditions for stay, education, training and development of all students of the school without exception: "A radical reform is needed that will stop the negative tendencies that will transform the Ukrainian school into a lever of social equality and cohesion, Development and Competitiveness of Ukraine ..." [4, p. 1]. In other words, the modern school is called to form a new generation of creative people, and it requires a revision of traditional approaches to the organization of educational process, the transition to new forms of work, the environment development in which the prominent place takes the individual approach to each child, taking into account its opportunities, abilities, needs and requests.

On the other hand, in line with international standards for the provision of educational services [9], Ukraine has taken a course towards the creation of a school of the 21st century, which would become a home for all students without exception and, above all, those who need special treatment, approach, assistance, that is children with special educational needs. And, therefore, it demonstrates the urgent need not only for reforming education in the context of the philosophy of humanism as a important element in the process of teaching and educating young people, but also creation of an inclusive environment that allows to educate a worthy change, people who are sincere and open, who are not indifferent to others who are ready to provide help, merciful and courageous.

\section{ANALYSIS AND DiscUSSION}

What the school today is like, determines the cultural level of society. In the context of the above, Paulo Freire's statement is relevant: "Humanist ideology implies laying the foundation for an educational policy of the principles of ... the care of each individual, and not just the mechanical observance of rights, which only exacerbates inequality" [5, p. 4]. Obviously, Ukrainian education should implement new approaches to education, upbringing and development of the individual, based on respect, equality, humane and tolerant attitude to a person, regardless of its nationality, age, gender, material wealth, opportunities, physical health, etc.

Secondly, the desire of the Ukrainian community to develop a humane civil society also implies an increase in the cultural level of the nation. Consideration of modern school education in the context of general culture is decisive in the process of re-evaluation and re-thinking of realities, identifying priority areas for the development of the educational sector. On the one hand, culture is the context that forms the personality [2, p. 6], on the other hand, education is an integral part of a common culture and aims at the cultivation of a cultural, spiritually rich, fully developed personality. Particular attention to such an approach deserves the separation of those areas of education, aimed at forming adequate to the social demands of the moral values of the individual, raising its spiritual and cultural level, ensuring comfortable living conditions.

It should be emphasized that the introduction into the educational process of the school of inclusive education is aimed at "ensuring affordable and quality education" for all, without exception, children of school age according to wishes or place of residence; creating comfortable conditions for their stay, training and development; formation of life-long-term competencies and "social integration of people with special needs", etc. [6, p. 17]. The modern school is designed to provide the maximum possible personal development of all students in accordance with their interests, needs, capabilities and abilities. It requires the creation of appropriate conditions for the implementation of state policy on the implementation of constitutional, as well as declared by international instruments [8] in the field of education, rights for people with developmental disabilities. So, according to the prominent American philosopher John Dewey: "The environment is any conditions that interact with human needs, desires, goals and abilities to shape experience..." [3, p. 42]. Therefore, today the problem of creating comfortable conditions for the comprehensive development of the individual, the education of a morally stable, spiritually rich, highly cultural personality, with persistent beliefs, based on deep respect and love for another person, is especially urgent. 
Practice shows that in connection with the adoption of the Concept of the Development of Inclusive Education from September 1, 2018, schools of Ukraine have been replenished with a large number of children with different types of nosologies. Of course, implementation of the approved decisions and resolutions of the Cabinet of Ministers of Ukraine required complex work on the adaptation and modification of educational institutions, environment, materials, etc. in accordance with the inclusive educational model. However, it does not mean that introduction of inclusion is not accompanied by a number of difficulties. Thus, one of them is the separation of people with special needs from other participants in the educational process of the school.

In the process of our study we aimed to find out the realities of school life and to diagnose the level of readiness of schools, and in particular, all participants of the educational process, in cooperation with children who have different types of developmental disorders. In this approach, by observing, conducting surveys, questionnaires, conversations with school teachers, students' parents, schoolchildren and others, we established the following:

- in general, there are no problems with the teaching of children in school with students who have special educational needs (100\%);

- the process of socialization of children with special needs from the point of view of their parents would be much more successful if the curriculum has some changes, the length of lessons and the load of students ( $45 \%$ of respondents);

- the success of students with special needs depends directly on their comfortable stay while studying at an institution, the appropriate conditions, attention from the teacher, the number of pupils in the classroom, the circle of communication (15\%);

- adaptation of primary school pupils with special needs to study at a secondary school, their circle of communication, friendly relations directly depend on the attitude of others, their acceptance or vice versa alienation.

Our observation has shown that most participants of the educational process of the school with inclusive education believe that students with disabilities in development quickly "stand out" in the environment of peers; on the part of the teacher, they pay more attention than others (26\% of respondents). On the contrary, the students' parents claim that they are mostly in a friendly relationships with the inclusive children's families. So, in our research, we found that $2 \%$ of parents regularly conduct ethical conversations with their own children on the topic of attentive attitude to others, which prevents any misunderstandings and conflicts. Our survey showed that among all the parents of healthy children, the majority did not see a problem (98\%) with schoolchildren who have special needs, and only $2 \%$ of those surveyed stricktly opposed such inclusion, because of their consideration of the place of such pupils - in a specialized educational institution.

As we have found later, where there are firm objections of parents, there may be some misunderstandings on the part of the students themselves, because the family is the primary source of upbringing of the individual and everything that children observe in the family, they reflect in interaction with others (See Figure 1):

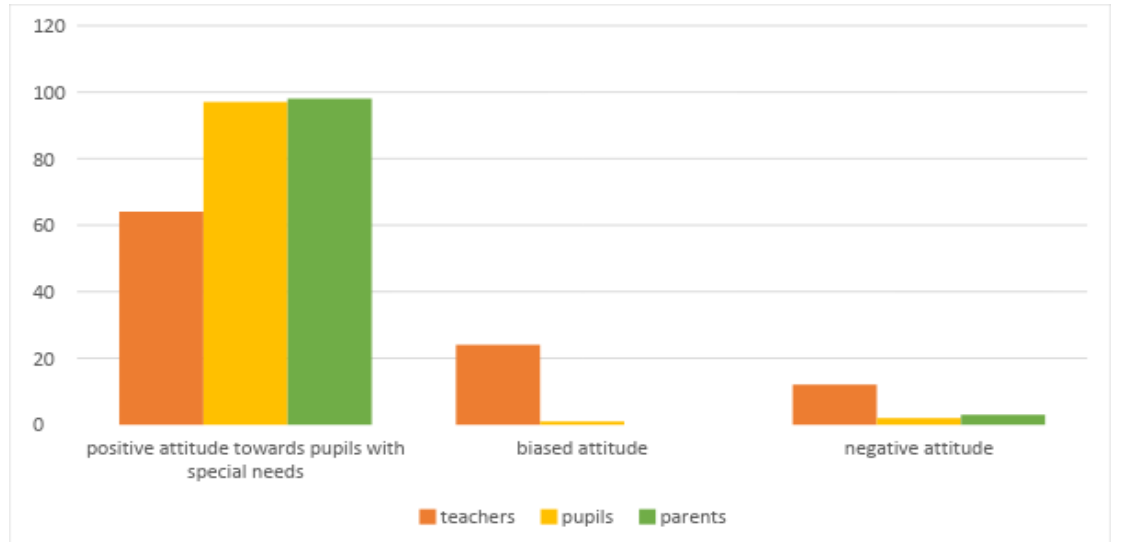

Fig. 1. Perception of pupils with special educational needs by the participants of the educational process. 
Based on the pictured in Fig. 1. we consider it necessary to emphasize the fact that, despite the small percentage of people who are negatively oriented towards pupils with developmental problems, the issue does not disappear, but requires careful study and the search for ways to prevent and overcome it. In our view, the level of readiness for admission to school of children with special needs deserves attention from teachers, students' parents and other participants in the educational process (See Figure 2):

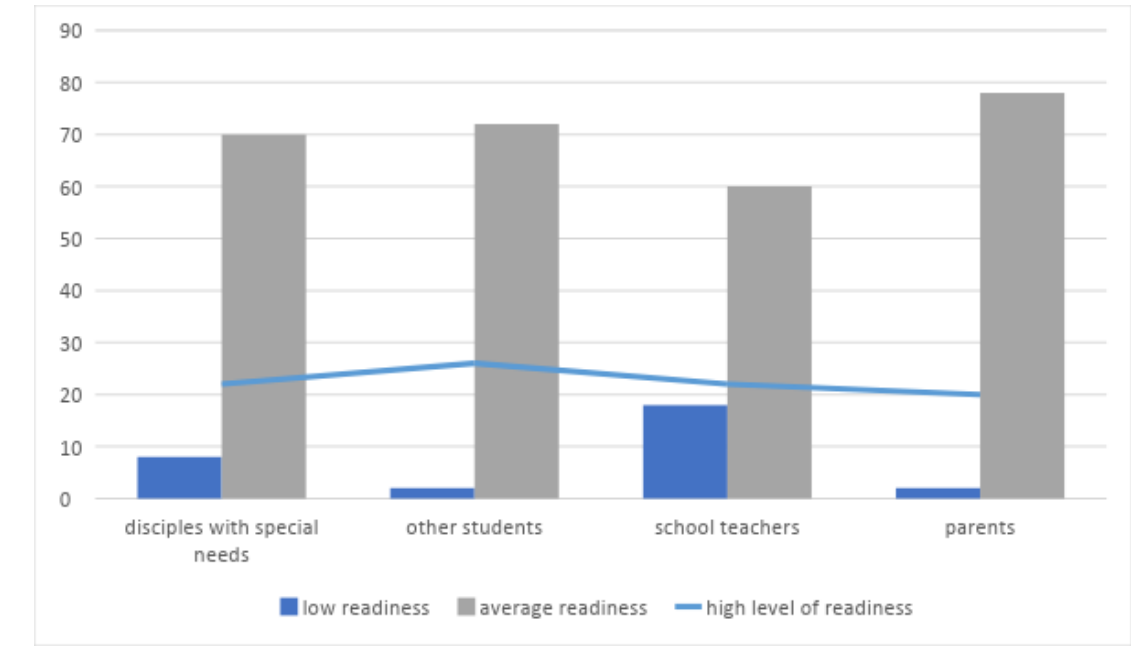

Fig. 2. Indicators of the level of readiness of the participants in the educational process of the school with inclusive education.

From our point of view, the effective method is the study of the factors that influence the emergence of negative attitude, which further provokes the emergence of conflicts in the process of learning between students. On the other hand, the identification of forms, methods, means of educational influence on schoolchildren regarding the cultivation of cultural behavior, tolerant attitude to all people becomes of paramount importance.

In the context of the above, we consider it necessary to define the essence of the concept of "tolerance". Tolerance (translated from Latin "tolerantia" - patience) - tolerance towards people who are different in a certain respect. Thus, the ability to build relationships with others, respect and love for a person, regardless of its ability, physical health is an indicator of humanity, cultural and moral level, ethical beliefs of the individual. Today, when we try to create the New Ukrainian School, which is based on the laws of freedom of the individual, democracy and equality, the question of tolerance is one of the most important. Benevolence and mercy, the ability to sympathize and empathize - are those moral qualities that continue to become vital in choosing priorities and values in the process of life. Scientists O. Dolin, V.Kotyrlo, S.Ladyvir, S.Kulachkivsky, Y.Pryhodko, S.Tishchenko emphasize that "by teaching children to be friendly and tolerant, any society will increase its moral capital, which will eventually be demanded by them. by itself, by every member of it ..." [7, p. 24]. Unfortunately, the realities of life and, in particular, school, testify that the cases of manifestation of cruelty and selfishness in school age children, indifferent attitude and unwillingness to help others, alienation or cowardice in making independent decisions. These and other aspects emphasize certain gaps in the process of upbringing of modern youth, and, therefore, in need of defining the main tasks for the formation of a morally stable and spiritually rich personality. Similarly, this problem is considered as requiring an immediate solution in terms of improving the efficiency of the introduction of inclusive education [8; 9] and the development of the New Ukrainian School, according to the Concept of which the key is: equal access to quality education of all children; through educational process that ensures the formation of important values; development of partnership relations between pupils and teachers; orientation towards the student's personality [4].

Consequently, in the process of education, it is necessary to form young people's abilities and skills of tolerant attitude towards people with peculiarities of their development, to work out moral and 
ethical norms, to reveal their inner world and to raise their cultural level. As our study showed, in the process of teaching and educating inclusive students, it is appropriate to single out a variety of different forms, methods and techniques that will eventually ensure achievement of high results.

The guiding principle in choosing the necessary forms and methods of work is an individual and personality-oriented approach that allows students to be better acquainted with special needs of other people. The systematic observation of this category of junior schoolchildren allows us to determine the specifics of work with them, study the inner world of children, determine their possibilities and individual characteristics, and, therefore, outline the ways for further educational work of the teacher with other students of the class (school). The basic requirements for the implementation of educational work with all, without exception, junior school students are: systematic and consistent acquaintance with each child; diagnosing the level of readiness for staying and studying in an educational institution, adaptation and socialization of students; involvement in various activities; educational work with parents, etc.

During the monitoring of junior school students, we found that most students positively perceive those students who have certain disruptions in development: in the majority of cases children do not see something that distinguishes such pupils, but their positive sides. As an example, the results of the survey of junior schoolchildren showed that they see positive qualities of their classmates with special educational needs, namely: courtesy $(32 \%)$, sociability $(11 \%)$, courage $(2 \%)$, kindness $(25 \%)$, ability to read well, to paint beautifully (to sculpt, to make applications) (10\%), a desire to study well (17\%). These and other indicators suggest that younger pupils are in friendly relationships, have a positive attitude toward learning with other students, do not notice any disadvantages and are ready to help when needed. However, sometimes you can observe the reluctance of friends, share educational materials, help, communicate, etc. In this case, teachers should carefully study the situation, determine the factors of influence on the conflict emergence, correctly select the methods of work with students, provoking their occurrence or exacerbation. This is facilitated by the use of a number of forms and methods of educational work, namely:

1. Conducting ethical conversations.

If necessary, the teacher should conduct individual, group or collective conversations on various moral and ethical themes ("All people deserve happiness", "We are brothers and sisters on Earth", "Help the weaker"), which will serve the formation of moral norms and beliefs of students, imposition of universal values, which are fundamental in the development of personality.

2. Organization and conducting educational events, hours, excursions.

Educational work with junior pupils may include arranging meetings with famous people of the region, as well as with people with special needs that have been successful - athletes, artists, writers, etc. This form of educational work enriches younger students with new experiences, forms communication skills, interaction with this category of people, reveals their positive aspects and develops a sense of humane attitude towards each other. Instead, the teacher can arrange and organize excursions to specialized educational institutions, boarding schools, visiting which younger students can make a conclusion for the ambiguity of the situation of those children who need their help.

3. Installation of various kinds of holidays, based on the idea of respect, love, mutual assistance to all who surrounds us.

4. Activate to various activities junior pupils.

As an example, it can be socially useful (performing joint tasks and tasks), labor (intensive work on cleaning the classroom, providing assistance to the teacher and students, work in the school district or in the workshop of the educational institution), creative (work on the creation of own products from paper, wood, clay, cloth, natural materials, mastering of various crafts of the Ukrainian people), playing (arranging various games, creating game situations that allow you to focus on the need for a respectful attitude towards all $x$ people). In particular, arranging games at the lesson and outside allows the student to quickly and easily develop, without much effort, the moral qualities and qualities that are essential in the context of our study. As an example, it is advisable to play the game "Now to get acquainted". The purpose of the game is to familiarize students with the positive qualities of each other 
for the purpose of further supporting the positive. It is expected to conduct a game in breaks or during physical exercises. Rules of the game are as follows: younger students stand in circles. The previously selected lead player keeps a ball in hands, which is passed to other participants of the game, calling one positive trait of character. The student who received the ball should also name the positive feature or quality that he/she possesses. Thus, children determine their the positive qualities, better learning each other.

For example, you can conduct other types of games, such as the game "Associative series". This game can be conducted at the lesson of the native language, reading or during the educational period after lessons. The rules of the game are: the teacher offers students to understand the concept of "tolerance" in letters. Teaching materials and equipment: the teacher writes the word in letters on the board and also arranges it in a column. Younger students (according to the teacher's request) go out to the board and add positive features and qualities inherent to a tolerant person next to each letter ( $\mathrm{T}$ talented, tactful, O - objective, original, L - loyal, loving, E - energetic, effective, empathy, $\mathrm{R}$ - reliable, respectful, $\mathrm{A}$ - authoritative, active, $\mathrm{N}$ - noble, nice - $\mathrm{C}$ - caring, compassionate, $\mathrm{E}$ - empathetic, etc.). In general, this allows students to know not only others but also themselves better, reveals their own inner world and acquaints with the aspirations and interests of students with special educational needs.

5. The organization of exhibitions of students' work allows to accentuate the attention of all younger pupils to the strong, positive aspects of children with disabilities in development, and form the awareness that a person with certain disorders is unique and in the same way as others need to be appreciated.

6. Conducting various exercises, tasks as a character creating and developing.

In the process of exercising, junior schoolchildren reveal a student with special needs on the other hand, previously being unaware of them. For example, in the game "You look like me", which the teacher conducts in a group, the students look for common features and qualities of each other, which then, after discussion, are proclaimed for the class. Such a common search is urgent in the process of forming a tolerant attitude, as younger students form tolerance skills in relation to people with special needs.

Another exercise, "Tolerant personality": the teacher gives students a sheet of signs of a tolerant and unwitting person and invites them to attach these sheets to the corresponding column on the board. This exercise serves the development of critical thinking, develops the ability to analyze and synthesize, and from the point of view of educational effect - instills the desire of younger students to be cultural, sincere, open, sociable, sensitive, and merciful.

\section{CONCLUSIONS}

Consequently, the main tasks of the teacher of the New Ukrainian School are: to create the proper conditions for training, education and development of all students without exception; providing quality educational services; formation of life-long competences of junior pupils; creation of a developing inclusive environment that satisfies the needs and interests of students with special needs; organization and implementation of educational impact on students in order to prevent the emergence and overcoming of existing conflict situations in relation to students with disabilities in development. In our view, important in this context is the formation of moral norms, the development of moral and ethical features, qualities, the incorporation of universal values of junior schoolchildren, acting as regulators of their behavior, style of communication. Upbringing a tolerant, respectful to other people personality, despite individual peculiarities, features, and abilities, occupies today an important place in the educational process of each institution and continues to determine the improvement path of our society, its cultural and economic level of development. 


\section{REFERENCES}

[1] Budnyk O., Chervinska I., Blyznyuk T. Pedagogical Collaboration of Teachers and Parents with Children who have Special Educational Needs in Conditions of Inclusive Education. In: Próchniak A., Suchocka A.A. (Eds.) Problemy i perspektywy młodzieży we współczesnej Europie. Oficyna Wydawnicza Edward Mitek, Bydgoszcz; Akademia Pomorska, Słupsk, 2018, 85-93.

[2] Bolgarina V. Culturological approach to school management. Osnova, Kharkiv, 2006. (in Ukrainian)

[3] Dewey J. Experience and Education. Calvaria Publishing House, Lviv, 2003. (in Ukrainian)

[4] Concept of the New Ukrainian School. Available at: https://www.kmu.gov.ua/storage/app/media/reforms/ ukrainska-shkola-compressed.pdf (in Ukrainian)

[5] Freire P. Pedagogy of Freedom: Democracy and Civic Courage. Kyiv-Mohyla Academy, Kyiv, 2004. (in Ukrainian)

[6] Kolupaieva A. The Strategic Vectors of Changes and Transformations in Education of Children with Special Needs Underlines in Ukraine. In: Zasenko V.V., Kolupaieva A.A. (Eds.) Education of people with special needs: ways of development, 13. LLC OUR PRINTING, Kyiv, 2017, 12-18. (in Ukrainian)

[7] Ladyvir S., Dolynna O., Kotyrlo V., Kulachkivska S., Tyshchenko S., Vovchyk-Blakytna O., Prykhodko Yu. Education of Humane Feelings in Children. Mandrivets, Ternopil, 2010. (in Ukrainian)

[8] Declaracion de Salamanca y Marco de Accion. Para Las Necesidades Educativas Especiales. Aprobada por la Conferencia Mundial Sobre Necesidades Educativas Especiales: Acceso y Calidad. Salamanca, España, 7-10 de junio de 1994 [Salamanca Declarations. Frames for action on Education for persons with special needs, adopted by the World Conference on Special Needs Education. Salamanca, Spain, 7-10 July, 1994]. (in Spanish)

[9] Annuaire statistique de l'UNESCO, 1999 [UNESCO statistical yearbook, 1999]. UNESCO, Paris, 1999. (in French)

Address: Nataliia Matveieva, Vasyl Stefanyk Precarpathian National University, 57, Shevchenko Str., IvanoFrankivsk, 76018, Ukraine.

E-mail: nataliematveieva@gmail.com

Received: 11.12.2018; revised: 14.03.2019.

Матвеєва Наталія. Формування у молодших школярів навичок толерантного ставлення до осіб з особливими потребами. Журнал Прикарпатського університету імені Василя Стефаника, 6 (1) (2019), $60-66$.

У статті обгрунтовано актуальність проблеми виховання толерантного ставлення мододших школярів до осіб з особливими освітніми потребами. Здійснено аналіз рівня готовності усіх учасників освітнього процесу до спілкування, спільного перебування, навчання із учнями з порушеннями у розвитку; специфіку виховного впливу на молодших школярів щодо формування у них стійких моральних переконань, виховання моральних рис та якостей, розвитку духовності, прищеплення цінностей, які $є$ основними й необхідними у контексті створення інклюзивного, розвивального, виховного середовища Нової української школи. Акцентовано увагу на необхідності включення усіх без винятку учнів у різні види діяльності, організації та проведенні спільних творчих справ, виховних заходів та ігор задля розкриття внутрішнього світу дітей, вивчення їх особливостей, зміцнення дитячого колективу. Наголошено на тому, що дотримання низки вимог дозволяе підвищити ефективність процесу виховання толерантного ставлення до дітей з особливими потребами.

Кдючові слова: діти 3 особливими освітніми потребами, інклюзивне навчання, індивідуальний підхід, адаптація, модифікація, рівність, виховання, толерантність. 